\title{
Biografilia: przypadek Petera Ackroyda
}

Ewa Kraskowska

TEKSTY DRUGIE 2019, NR 1, S. 28-40

DOI: $10.18318 /$ td.2019.1.3 | ORCID: 0000-0003-4316-1675

\section{I}

Terminem „biografilia” posłużyła się Cora Kaplan jako tytułem jednego z rozdziałów swojej książki Victoriana. Histories, Fictions, Criticism opublikowanej w 2007 roku. Z kolei występujące w tytule owej książki „wiktoriana” to pojemne określenie odnoszące się do różnych przejawów nurtu neo- (albo, jak wolą niektórzy, post-) wiktoriańskiego we współczesnej kulturze anglosaskiej. Nurt ten szeroko płynie w beletrystyce, w sztuce filmowej i teatralnej, w pisarstwie historycznym i w dyskursie akademickim, znakomicie funkcjonuje i w obiegu wysokoartystycznym, i w popkulturze, choć największe sukcesy święci w kulturze tzw. middlebrow - średniego lotu. Jego początków można się doszukiwać w latach 6o. ubiegłego wieku: w powieściach Wide Sargasso Sea (1966, pol. Szerokie morze Sargassowe) Jean Rhys i The French Lieutenant's Women (1969, pol. Kochanica Francuza) Johna Fowlesa, postrzeganych przez krytykę literacką w kontekście postmodernistycznym. Wespół z takimi komponentami, jak dyskurs postkolonialny i feministyczno-genderowo-queerowy - z którymi od samego początku wchodzi w tematyczne,

\section{Ewa Kraskowska}

- profesorka w Instytucie Filologii Polskiej Uniwersytetu im. Adama Mickiewicza w Poznaniu. Specjalizuje się $w$ badaniach nad pisarstwem kobiet i nad przekładem literackim. Ostatnio opublikowała książkę "Tyłem, ale naprzód". Studia i szkice oThemersonach (Poznań 2018). Pod jej kierunkiem powstała monografia zbiorowa Polskie pisarstwo kobiet w wieku XX: procesyigatunki, sytuacje i tematy (2015). 
ideowe i estetyczne alianse - w latach 8o.i 9o. neowiktorianizm wkroczył do mainstreamu anglojęzycznej literatury i sztuki, odmieniając jej oblicze i trwając w niej do dziś. Jednym z jego aspektów jest rzeczona biografilia rozumiana przez Kaplan jako entuzjastyczna wręcz w naszych czasach "moda” (vogue) i "potrzeba” (urge) powrotu do pisarstwa biograficznego nawiązującego do XIX-wiecznych wzorców gatunku. W dzisiejszych biografiach literackich (tzn. mających za przedmiot żywot pisarza lub pisarki) - twierdzi Kaplan - dokonuje się odrodzenie wielkiego realizmu i triumfalne zmartwychwstanie autora jako bohatera zbiorowej wyobraźni, lekkomyślnie uśmierconego pół wieku temu przez Barthes'a i Foucaulta. Jej zdaniem w istocie książka biograficzna zastępuje współczesnym czytelniczkom i czytelnikom klasyczną powieść realistyczną, a wpływ biografilii rozszerza się na różne inne formy prozatorskie opatrywane przez krytyków i badaczy wspólnym mianem biofikcji'.

Związek sztuki biografii z epoką wiktoriańską w kulturze anglosaskiej był wielowymiarowy i promieniował na czasy późniejsze, modernistyczne. Bodaj najlepiej jest on uchwytny, gdy pod tym kątem przyjrzeć się twórczej konstelacji osobowej, w której centrum znajduje się Virginia Woolf. Jej ojciec, sir Leslie Stephen, reprezentuje w tejże konstelacji konserwatywną tradycję biografistyki XIX-wiecznej. Należał on do brytyjskiej elity intelektualnej drugiej połowy XIX wieku, był pisarzem, historykiem filozofii, krytykiem literackim i wykładowcą Trinity College w Cambridge, a jako biograf zasłynął m.in. książkami o Samuelu Johnsonie, Aleksandrze Pope, Jonathanie Swifcie i George Eliot. Począwszy od 1882 roku, był intensywnie zaangażowany w wielki projekt leksykograficzno-biograficzny wydawnictwa Smith, Elder, \& Co. - redakcję, wspólnie z Sidneyem Lee, Narodowego Stownika Biograficznego (Dictionary of National Biography).W sumie do roku 1901, kiedy to projekt sfinalizowano, ukazały się aż sześćdziesiąt trzy woluminy i trzy suplementy, do których hasła (w liczbie 27 236, z czego 3,5\% dotyczyło kobiet) napisało sześciuset czterdziestu siedmiu autorów, sam zaś Stephen, mający naturę ekstrawertyczną i wybuchową, nieraz głośno złorzeczył pod adresem „przeklętego słownika"2. W cieniu owego monumentalnego i skomplikowanego

1 C. Kaplan Victoriana. Histories, Fictions, Criticism, Edinburgh University Press, Edinburgh 2007, s. 7-8, 37-84.

2 Informacje o DNB zaczerpnęłam z książki Juliette Atkinson Victorian Biography Reconsidered: a Study of Nineteenth-Century 'Hidden Lives', Oxford University Press, Oxford-New York 2010. Korzystam tu również z mojego artykułu Virginia Woolf i sztuka biografii, "Magazyn Literacki. Dodatek do Tygodnika Powszechnego" 2011 nr 3/4. Spośród przedwiktoriańskich biografii najważniejszym osiągnięciem, inspirującym żywotopisarstwo późniejszych epok, jest oczywiście 
logistycznie, metodologicznie i merytorycznie przedsięwzięcia upływało dzieciństwo i młodość przyszłej autorki Pani Dalloway.

Na przeciwległych krańcach Woolfiańskiej konstelacji znajdziemy Lyttona Stracheya - chyba najbardziej ekscentryczną postać i tak przecież mocno queerowej grupy Bloomsbury, homoseksualistę, a w pewnym momencie całkiem poważnego kandydata na męża Virginii. Za sprawą wydanej w roku 1918 książki Eminent Victorians autor ten odmienił oblicze brytyjskiej biografistyki, przenosząc ją z dziedziny pisarstwa naukowego do beletrystyki. Wychodząc z założenia, że dzieje epoki wiktoriańskiej nie są możliwe do napisania z powodu zbyt wielkiego natłoku informacji zmagazynowanych w trakcie jej trwania, Strachey uznał, iż rozsądny historyk powinien zrezygnować z ambicji tworzenia skrupulatnej narracji całościowej i przyjąć strategię bardziej subtelną, ujmując przedmiot z niespodziewanej strony, z boku lub z tyłu, oświetlając ukryte zakamarki. „Podjąłem próbę ukazania nowoczesnemu oku pewnej wizji epoki wiktoriańskiej za pośrednictwem biografii. [...] chciałem tę epokę raczej zilustrować niż wyjaśnić" - pisał we wstępie do swojego dzieła ${ }^{3}$, w którym zawarł sylwetki czterech skrajnie różnych, a reprezentatywnych dla epoki postaci: katolickiego konwertyty kardynała Manninga, prekursorki pielęgniarstwa Florence Nightingale, uczestnika amerykańskiej wojny domowej generała George'a Gordona i wybitnego pedagoga Thomasa Arnolda. W podobnym, mocno anegdotycznym stylu, ze sporą domieszką wchodzącej wówczas w modę psychoanalizy, utrzymana była kolejna z jego książek, wydana trzy lata później biografia królowej Wiktorii, oraz nieco późniejsza Elżbieta $i$ Essex (obie ukazały się po polsku w 1937 roku, wznowiono je w latach 1960 i 1958).

I wreszcie sama Virginia Woolf jako biografistka. Rzadko się dziś pamięta, że ma ona na koncie książkę poświęconą innemu bloomsburczykowi, malarzowi i krytykowi Rogerowi Fry'owi, którą napisała po jego śmierci w roku 1934. Pracę nad nią rozpoczęła cztery lata później, a rzecz ukazała się drukiem w roku $1940^{4}$. W pochodzącym z tego okresu eseju Sztuka biografii pisała:

Life of Samuel Johnson z roku 1791, autorstwa zaprzyjaźnionego z wielkim pisarzem i leksykografem Jamesa Boswella (pol. Żywot doktora Samuela Johnsona, przeł. T.J. Dehnel, Warszawa 1962).

3 L.Strachey Eminent Victorians, The Echo Library, Teddington 2006, s. 1 [przeł. E.K.].

4 V. Woolf Roger Fry: A Biography, Hogarth Press, London 1940. W tym miejscu warto przypomnieć, że dwa spośród opublikowanych przez Woolf utworów powieściowych noszą podtytuł a biography. Są to Orlando i Flush, wyróżniające się na tle dorobku prozatorskiego autorki Fal 
Biografię robi się z pomocą przyjaciół i faktów, powieść tworzy się bez jakichkolwiek restrykcji poza tymi, jakich spodoba się przestrzegać danemu artyście z powodów, które jemu wydają się słuszne. To pewna różnica i mamy powody przypuszczać, że w przeszłości biografowie nie tylko poznali tę różnicę, ale także odczuli jej bezwzględność. [...] Przypuśćmy, na przykład, że nasz geniusz był człowiekiem niemoralnym, nieznośnym i ciskał za pokojową butami. Wdowa powie: „A jednak kochałam go, był ojcem moich dzieci, toteż czytelnik, który uwielbia jego książki, pod żadnym pozorem nie może zostać rozczarowany. Proszę to zatuszować, pominąć". I biograf posłucha. Dlatego większość wiktoriańskich biografii przypomina przechowywane dziś w Westminster Abbey woskowe figury, które kiedyś niesiono ulicami w orszaku pogrzebowym - figury obdarzone tylko ulizanym podobieństwem do zmarłego leżącego w trumnie. ${ }^{5}$

W świetle perypetii sądowych, jakie przydarzają się współczesnym biografom i biografkom stosunkowo niedawno zmarłych osobistości, powyższy komentarz Woolf nie traci żywej aktualności. Jednak w odniesieniu do pisanych w naszych czasach żywotów postaci historycznych obowiązują już całkiem inne trendy, których dobrą ilustracją jest przypadek Petera Ackroyda - autora, dla którego biografia stała się gatunkiem koronnym i totalnym.

II

Twórczość Petera Ackroyda (rocznik 1949) można postrzegać w jednym kontinuum z pisarstwem Virginii Woolf i T.S. Eliota, co nie oznacza zresztą, że potomność przyzna mu rangę literacką równą tej, którą cieszy się tych dwoje. Problemem autora Dickensa i Chattertona stało się bowiem to, iż od dłuższego czasu rozmienia on swój wielki talent na drobne, daje się wchłonąć rynkowi i produkuje kolejne książki (w rodzaju choćby biografii Hitchcocka czy Chaplina) już nie dla sztuki, lecz najwyraźniej pod publikę i w celach komercyjnych. Żywiąc dlań wszakże nieustającą estymę i czytelniczą słabość, tym wątkiem zajmować się nie będę. Stawiam jego nazwisko w jednym rzędzie

zarówno tematem, jak i formą. Ona sama pisała o nich w dzienniku jako o trifles - błahostkach

- mając na myśli ich żartobliwość i fantastyczność.

5 V. Woolf Pochyła wieża, przeł. E. Życieńska, Warszawa 1977, s. 330-331. 
z największymi osobistościami brytyjskiego modernizmu, mając na myśli szereg cech wspólnych ich utworom i postawom twórczym.

Więc, po pierwsze, Londyn - wszyscy troje zanurzeni są w klimatach tego miasta i jako jego mieszkańcy, i jako piewcy londyńskości, co w przypadku Ackroyda przybiera formę iście zachłanną: o czymkolwiek on pisze, zawsze pisze o Londynie. Polski badacz twórczości Petera Ackroyda, Tomasz Niedokos z Katolickiego Uniwersytetu Lubelskiego, rozpatruje tę szczególną monotematyczność autora Manifestu dla Londynu jako główny wyznacznik jego myślenia o kulturze angielskiej w ogóle; Londyn to dlań miejsce, gdzie „wyobraźnia angielska i w konsekwencji angielska kultura mogą być oglądane $\mathrm{i}$ analizowane in statu nascendi, w najbardziej żywotnych i dynamicznych przejawach, w dziełach londyńskich «luminarzy» $\mathrm{i}$ «wizjonerów»".

Po drugie - awangardowość i eksperymentowanie z formą. Jeśli idzie o Woolf i Eliota, kwestia ta nie wymaga dopowiedzenia, natomiast awangardowość Ackroyda najlepiej widać w kontekście lat 70. i 80. XX wieku, kiedy to był on młodym, szybko zdobywającym rozgłos autorem najpierw utworów poetyckich pisanych pod wpływem nowojorczyków Johna Ashbery'ego, Franka O'Hary i Kennetha Kocha, następnie krytykiem i redaktorem literackim tygodnika „Spectator”, by wreszcie zadebiutować jako prozaik w roku 1982 powieścią The Great Fire of London (intertekstualnie związaną z Mała Dorrit Charlesa Dickensa) i od tego momentu z zadziwiającą płodnością oddawać do druku kolejne dzieła. Ackroyd miał wówczas za sobą dwuletnie (1971-1973) stypendium w Yale, owej mekce amerykańskiego dekonstrukcjonizmu i postmodernizmu, i wpływ tej szkoły na rozwój jego pisarstwa jest nie do przecenienia. Z lat 70. pochodzą jeszcze pisane przezeń pod wpływem French Theory, a chłodno przyjęte w Wielkiej Brytanii Notes for a New Culture, studium Ezra Pound and His World oraz znamienna, jak się miało okazać, książka Dressing Up, Transvesticism and Drag: The History of an Obsession. Znamienna, gdyz - i to po trzecie - wątki kampowe i queerowe, charakterystyczne dla subkultury bloomsburczyków i dla samej Woolf, nieco słabiej wyczuwalne u Eliota7, weszły na stałe do literackiego uniwersum Ackroyda,

6 T. Niedokos The Concept of English Culture in the Cultural Biographies of Peter Ackroyd, Wydawnictwo KUL, Lublin 2011, s. 64 [przeł. E.K.] A Manifesto for London to jeden z esejów o tematyce londyńskiej zebranych w P. Ackroyd The Collection, ed. by T. Wright, Vintage, London 2002. $Z$ tego zbioru pochodzi również cytowany przez Niedokosa tekst Ackroyda London Luminaries and Cockney Visionaries.

7 Można zwrócić uwagę chociażby na występującą w Ziemi jałowej postać Tejrezjasza, który tak jak Orlando/Orlanda z powieści Woolf jest i mężczyzną, i kobietą oraz zna przeszłość i przy- 
łącząc się płynnie z londyńskością i pisarskim eksperymentatorstwem8 ${ }^{8}$.Jego najnowsza niepowieściowa książka to Queer City: Gay London from the Romans to the present day (2017).Twórczość Ackroyda ewoluowała od zainteresowania wysokim modernizmem, przez własną dojrzałą fazę postmodernistyczną, by w XXI wieku stopniowo od postmodernizmu odchodzić w kierunku z jednej strony coraz bardziej popularyzatorskich projektów (w rodzaju zakrojonej na sześć obszernych tomów The History of England), a z drugiej - postpostmodernistycznych koncepcji silnego autorstwa, przejawiających się choćby w tworzeniu wyrazistej marki pisarskiej. Pisarz wyraźnie oddala się od metafikcji, dając pierwszeństwo historiografii, a równolegle z tym procesem daje się zauważyć w jego postawie swoisty zwrot postsekularny - o czym będzie mowa pod koniec tego artykułu.

W roku 1984 ukazała się druga - po wczesnym studium o Poundzie z książek biograficznych Petera Ackroyda, rozpoczynająca serię żywotów wielkich londyńczyków jego autorstwa: T.S. Eliot. Została przyjęta z dużym aplauzem i nagrodzona Whitbread Award for Biography. Od tej pory proza powieściowa i proza biograficzna nieustannie się w jego dorobku przeplatają, a raczej splatają w jeden wielce złożony wzór ${ }^{9}$, w którym funkcję strukturalnej kanwy pełnią polifoniczność i intertekstualność - cechy, które na gruncie modernizmu najpełniej objawiły się nie gdzie indziej, jak właśnie w Ziemi jatowej Eliota. W poemacie tym spożytkowany został również chwyt, który u Ackroyda zagości na stałe, mianowicie łączenie współczesnych planów czasowych z odległą przeszłością, wskazywanie między nimi znaczących analogii i tożsamości, wielka projekcja diachronii w synchronię, wskutek której to, co przeszłe, nigdy nie jest do końca minione, bo zawsze prześwituje

szłość. Cross-dressing jest kluczowym motywem powieści Ackroyda Dan Leno i Golem z Limehouse, a wędrówkę poprzez wieki uprawia wszak on sam, czy też raczej jego autorskie i narratorskie persony.

8 Moja znajomość ogólnych faktów biobibliograficznych związanych z Ackroydem pochodzi z tak wielu różnych źródeł (prasa papierowa i internetowa, opracowania akademickie, wywiady, parateksty itd.), że trudno byłoby mi za każdym razem wskazywać konkretne odwołania. Pozwolę sobie więc na użytek tego artykułu z nich zrezygnować. Nie dotyczy to oczywiście rozpoznań o charakterze interpretacyjno-badawczym.

Co ciekawe i, jak mi się zdaje, warte odnotowania, zawsze są to biografie rodzaju męskiego, choć przecież bez trudu można znaleźć wybitne autorki związane z Londynem - od George Eliot i Virginii Woolf poczynając - o których Ackroyd mógłby pisać. Jest to o tyle uderzające, że analizowana przez Corę Kaplan współczesna "biografilia” charakteryzuje się m.in. właśnie wzmożonym zainteresowaniem dla żywotów kobiecych. 
przez teraźniejszość. Ackroydowski narrator stale będzie wypatrywał takich prześwitów, tajemniczych i często groźnych miejsc, kanałów, przez które z łatwością można się osunąć w inny czas. Tak dzieje się choćby w powieści Dom doktora Dee, gdzie tytułowe lokum, czyli niewielka kamienica w londyńskiej dzielnicy Clerkenwell odziedziczona przez współczesnego bohatera i zarazem pierwszoosobowego narratora, zachowało ślady zamieszkiwania przez słynnego alchemika i astrologa z epoki elżbietańskiej, Johna Dee - postać najzupełniej historyczną. Co z tego wynika, zdradzać nie będę, gdyż jest to thriller gotycki i nie należy jego fabuły spoilerować.

Ackroyd pojmuje przeszłość na modłę postmodernistyczną - jako dyskursywny konstrukt i wytwór narracji, które można czytać tak, jak narracje fikcjonalne - ale zarazem arystoteliańską: mimesis, którą dlań jest powieść, "prawdziwsza" jest od historiografii, którą reprezentuje tradycyjne pisarstwo biograficzne. Dlatego biografistykę trzeba upowieściowić. T.S. Eliot rozpoczął serię książek, które stały się znakiem markowym Ackroyda. Są wśród nich dzieła bez mała monumentalne, jak Dickens, Blake, The Life of Thomas More czy Shakespeare: The Biography, ale także tzw. brieflives: Chaucer,J.M.W.Turner, Newton, Poe: A Life Cut Short, Wilkie Collins i wspomniane już tu Hitchcock oraz Chaplin. Objawił się on w nich jako twórca własnej, oryginalnej formuły żywotopisarstwa, a najwybitniejszą jej realizacją stał się ponadtysiącstronicowy tom o Charlesie Dickensie z 1990 roku.

Jednym z chwytów chętnie stosowanych przez Ackroyda jest imitowanie stylu pisarzy, o których opowiada, stąd w opiniach krytyków, zwłaszcza tych prasowych, dorobił się on miana brzuchomówcy (ventriloquist). Sposób ten wypróbowywał z dobrymi efektami na gruncie powieściowym w takich dziełach jak choćby The Last Testament of Oscar Wilde (1983) czy Chatterton (1987). Przeniesiony do narracji o życiu i twórczości, skutkował on kontrowersyjną dla niektórych odbiorców literaturyzacją gatunku, wzmacnianą dodatkowo wkomponowywaniem w tekst biografii fragmentów o jawnie fikcyjnym charakterze. Tak dzieje się przede wszystkim w Dickensie, gdzie tekst główny przetykany jest licznymi wstawkami retorycznymi tudzież udramatyzowanymi scenkami w rodzaju rozmowy „autora” (Ackroyda) z Dickensem w londyńskim metrze czy dialogów między postaciami z różnych powieści tego ostatniego. Cora Kaplan, która nader sceptycznie odnosi się do takich chwytów, nazywa je „minipsychodramami” i uważa, że jest to „niezręczny ukłon w stronę postmodernistyczności współczesnej biografii”10. Głównie

10 Kaplan Victoriana..., s. 57. 
bowiem ma za złe Ackroydowi, że jego wizerunek Dickensa jest z gruntu heglowski, naznaczony esencjalistycznym myśleniem o podmiocie, autorze i autorstwie oraz romantyczną koncepcją geniusza, w którego dziele i życiu uobecnia się Zeitgeist.

Wydaje się jednak, że bardziej niż romantyczne teorie zaważyła na metodzie Ackroyda spuścizna filozoficzno-antropologiczna pozytywizmu i Hipolita Taine'a z jego przekonaniem, że fenomen twórcy można zrozumieć, badając „, siły pierwiastkowe”, które go stworzyły: czas (moment historyczny), miejsce (środowisko), rasę i klasę (plemienność). „Pozostawiajmy - pisał Taine - na stronie teorie o konstytucjach i ich mechanizmach, o religiach i ich systemach, a usiłujmy widzieć ludzi w warsztatach, w biurach, na polach, ludzi wraz z ich niebem i ziemią, domami i odzieżą, z różnorodną ich uprawą i codziennym posiłkiem, usiłujmy przypatrywać się im tak, jak, wstępując na wybrzeże Anglii lub Włoch, przypatrujemy się twarzom i gestom ludzkim, chodnikom i publicznym gospodom, przechadzającym się mieszkańcom miasta i pijącym robotnikom. Największym staraniem naszym powinno być zastąpienie, o ile podobna, przez wiedzę i wyobraźnię, spostrzegania naocznego, osobistego i bezpośredniego, które nie jest już nam dostępnem; bo tylko takie spostrzeganie jest drogą, na której możemy poznać człowieka"11. A ponieważ jedynym miejscem na ziemi, które interesuje Petera Ackroyda i w którym upływa jego życie, jest - jak wiadomo - Londyn, toteż bohaterowie jego biografii i powieści są przede wszystkim wytworami londyńskości. Więc jednak geniusz - genius loci.

Pisarz tylko dwukrotnie opuścił na dłużej swoje miasto, najpierw za młodu, gdy wyjechał na stypendium do Yale, oraz pod koniec XX wieku, gdy za zaliczkę na Dickensa nabył dom w hrabstwie Devon i zamieszkał tam ze swym partnerem, tancerzem Brianem Kuhnem. Po śmierci Kuhna na AIDS w 1994 roku wrócił do Londynu, nigdy się z nikim już nie związał, wiódł żywot samotniczy i - jak powiada - czysty (chaste), oddając się wyłącznie intensywnej pracy pisarskiej. Londynowi poświęcił swój wyjątkowy i ogromny projekt quasi-biograficzny, kilkusetstronicowy bestseller London. The Biography z roku 2000. I choć "biografia" miasta to nie jest genologiczny wynalazek Ackroyda - podobne tytuły wykorzystywano już wcześniej - lecz z pewnością to on, nie kto inny, wylansował tę formę historiograficzną, nadając jej swoje personalne piętno.

11 H. Taine Historia literatury angielskiej, przeł. E. Orzeszkowa, Warszawa 1900, s. 8. Tekst dostępny w bazie Polona. 


\section{III}

Jak zatem odróżnić „biografię” miasta od jego „historii”? W przypadku Londynu Petera Ackroyda istota zdaje się tkwić w samym rozumieniu terminu, bowiem tworzony przezeń portret metropolii nie sugeruje biograficzności w ogólnie przyjętym sensie linearnej narracji o zdarzeniach układających się w określony ciąg istnieniowy od początku (narodziny, powstanie) do końca (śmierć, zniszczenie). To raczej bio-grafia rozumiana jako opisanie żywego organizmu, jego anatomii i fizjologii. Pierwszy rozdział Londynu jest zatytułowany „Miasto jako ciało”12 i można w nim przeczytać, że „boczne uliczki Londynu przypominają cienkie żyły, a parki są jak płuca”, „miasto jest tłuste i żarłoczne [...], spożywa i wydala”, ,jego ciało, trawione gorączką, [... żyje od zarazy do pożaru" (19). Koncepcja książki, jej treściowa zawartość i cała retoryka, opiera się na podobnej topice monstrualno-korporalnej, czasami kontrapunktowanej akcentami kojarzącymi się z życiem intelektualnym i duchowym. Ackroydowski Londyn jest żywy, żyjący i żywotny, rządzi nim, jak każdym organizmem, „paradoks nieustannej zmiany i niezmiennej wewnętrznej tożsamości" (137), poszczególne jego komórki ulegają wymianie, ale funkcje narządów są wciąż te same. Na podstawie pism Ackroyda (powieści i książek niepowieściowych) Tomasz Niedokos sporządził listę miejsc londyńskich (dzielnic, ulic, placów, targów) składających się na mapę „rezonansów chronologicznych”, gdzie te same elementy (czynności, dźwięki, zapachy itp.) istnieją od stuleci. Są wśród nich m.in. Drury Lane (teatr), Covent Garden (targ warzywny), Lincoln Inn's Field (miejsce, gdzie gromadzą się bezdomni), Endell Street (publiczne łaźnie), Smithfield (targ mięsny), Turnmill Street (ulica prostytutek), narożnik Leadenhill St. i Mitre St. (teren cmentarny) i wiele innych ${ }^{13}$.

Przemierzając londyńskie trakty, narrator Ackroyda tak właśnie odczuwa przestrzeń: jako rodzaj tunelu wiodącego w głębiny czasu. Sprzyja temu fakt, że współczesna mapa miasta istotnie zachowuje zarysy dawniejszej topografii, trzeba tylko umieć to zobaczyć i wyrazić: „w miejscu dzisiejszego skrzyżowania Angel w Islingtonie przecinały się dwie prahistoryczne brytyjskie drogi” (32). W sukurs często przychodzi mu archeologia, gdyż „nic nie jest na zawsze stracone" (31). W glinie, z której zrobiona jest londyńska cegła, znaleziono namacalne ślady prehistorycznej przeszłości: szkielet rekina,

12 Wszystkie cytaty z tej książki za: P. Ackroyd Londyn. Biografia, przeł. T. Bieroń, Zysk i S-ka, Poznań 2011. Numery stron będę podawać bezpośrednio przy cytowanych fragmentach. 
czaszkę wilka, szczątki mamuta, odłamki krzemiennego toporka. Równie wiele śladów przeszłości zachowało się w toponomastyce, np. „w średniowiecznym Londynie istniała Dark Lane, przy której stała karczma zwana Darkhouse. [...] Dzisiaj znajduje się tutaj Dark House Wharf, zdominowany przez centralę Bank of Hong Kong. Budynek ten jest pokryty ciemnoniebieską stalą i przyciemnionym szkłem. A zatem miasto nadal strzeże mrocznych tajemnic swego życia" (127). Wyobraźnia Ackroyda nie ustaje w poszukiwaniu (lub wytwarzaniu) takich znaków organicznej ciąłości. W jego opowieści o Londynie prawie nie ma miejsca dla pierwszoplanowych osobistości historycznych, jeśli się tu pojawiają, to na prawach wzmianki. Nie ma też tzw. wysokich sfer, londyńskiej socjety. Główne role zostały zarezerwowane dla anonimowych mieszkańców miasta wiodących tu swe pracowite życie, dla londyńskiego tłumu, dla wyrzutków, dziwaków, przestępców i wszelkiego autoramentu ekstraordynaryjnych figur (rozdział Londyńskie wyrzutki) zaludniających "doły materialno-cielesne" - by użyć terminu Bachtina - gigantycznego miasta. Szczególną bowiem fascynację budzi u Ackroyda wszystko, co wiąże się z podstawowymi funkcjami fizjologicznymi: jedzenie, trawienie, wydalanie, rozwiązłość seksualna („londyński krajobraz seksualny od zawsze znamionuje żarłoczność i nienasycenie”, 402), epidemie zarazy i choroby weneryczne. A także Londyn podziemny (ścieki, tunele, korytarze, Underground), smród, hałas, zbrodnia, przemoc, magia, okultyzm i wizjonerstwo. Słowem - prawdziwe Miasto grzechu, jak głosi tytuł jednego z rozdziałów.

Z myślą bachtinowską kojarzyć można jeszcze inną cechę Ackroydowskiego Londynu: jego ludyczność i teatralność. To rzeczywistość do cna skarnawalizowana, obraz świata na opak, gdzie spektakl toczy się w teatrze i music-hallu, lecz przede wszystkim, ku uciesze gawiedzi, na zatłoczonych ulicach i jarmarkach miasta, również w miejscach publicznych egzekucji, przy pręgierzu. Każda okazja do rozrywki była tu skrzętnie wykorzystywana, bo pozwalała na moment oderwać się od z gruntu ponurej, beznadziejnej egzystencji.W interpretacji Ackroyda Londyn to bezwzględne monstrum, lecz nie ma w tym obrazie intencji potępienia. Jest za to podziw dla niezniszczalnej, plebejskiej witalności miasta i jego mieszkańców, i jest zachwyt jego ogromem, różnorodnością, widowiskowością. Wodewilową subkulturę lat 8o. XIX wieku odtwarza neowiktoriański thriller Ackroyda Dan Leno i Golem z Limehouse z 1994 roku - powieść intertekstualnie (ale przewrotnie) nawiązująca do historii Kuby Rozpruwacza, do praskiej legendy o Golemie oraz do eseju Thomasa de Quinceya $O$ morderstwie jako jednej ze sztuk pięknych. Tytułowy Dan Leno to postać autentyczna, słynny komik i parodysta, uwielbiana przez 
cockneyowską widownię gwiazda londyńskiego music-hallu, znany z niebywałego talentu do wcielania się w różne postacie, zwłaszcza kobiece. Obok niego pojawiają się w fikcyjnej rzeczywistości takie osobistości XIX-wiecznego Londynu, jak Karol Marks, George Gissing, Robert Louis Stevenson, Oskar Wilde czy Artur Conan Doyle, a sama narracja jest inkrustowana dokumentami z epoki: fragmentami doniesień prasowych, dokumentów sądowych, tekstów literackich. To Ackroydowski postmodernizm w pełnym rozkwicie, zaspokajający gusta zarówno eksperckiej publiczności czytelniczej, jak i mniej wybrednych amatorów dobrej fabuły sensacyjno-kryminalnej.

Londyńska widowiskowość w ujęciu Ackroyda, również ta dawna, zdaje się mieć wyraźnie kampowy charakter - jeżeli termin camp potraktować ahistorycznie, opisowo. Jak się jednak okazuje, można ją też interpretować na inną, może zresztą nie tak całkiem odmienną modłę. I to jest dobry moment, by raz jeszcze, już na zakończenie tych rozważań, sięgnąć do monografii Tomasza Niedokosa. Lubelski anglista poświęcił bowiem swoją książkę udowodnieniu tezy o katolickości pisarstwa autora Londynu, ściślej - o ukrytej w nim katolickiej wrażliwości (buried Catholic sensibility), a żywioł widowiskowy umieścił wśród wielu wyznaczników tejże. Nie używając terminu postsekularyzm, w gruncie rzeczy taką właśnie diagnozę zaproponował w odniesieniu do dojrzałej i późnej twórczości Ackroyda.

Peter Ackroyd istotnie należy do licznej grupy angielskich pisarzy wyznania rzymsko-katolickiego i w dodatku tematyzujących tę kwestię w utworach literackich, a są w tej grupie nazwiska tak wybitne, jak choćby Gilbert K. Chesterton, Graham Greene, Evelyn Waugh czy David Lodge. „Katolicyzm Ackroyda - pisze Niedokos - [...] jest raczej natury kulturowej niż teologicznej czy doktrynalnej"14 i uściśla, że składają się nań liczne elementy charakterystyczne dla jego pisarstwa. Ich lista jest dość długa, ale warto je tu pokrótce wymienić, gdyż każdy z nich znajduje u Niedokosa interpretacyjne uzasadnienie i pobudza do reinterpretacji tego, co w kulturze polskiej potocznie kojarzy się z katolickim światopoglądem i estetyką. Są to zatem: wyobraźnia „analogiczna”, czyli skłonność do myślenia w kategoriach paraleli i odpowiedniości, postrzeganie przedmiotów i zdarzeń życia doczesnego jako „bram” do rzeczywistości transcendentalnej; związane z taką wyobraźnią umiłowanie rytuału, religijnych ceremonii i świąt oraz pojmowanie czasu jako cyklicznego raczej niż linearnego; pamięć zbiorowa i wytwarzane przez nią poczucie ciągłości. A dalej: częste sięganie przez Ackroyda do dziejów

Tamże, s. 70. 
Anglii sprzed Reformacji, uwrażliwienie na sensualne relikty katolicyzmu w kulturze angielskiej (np. dźwięk dzwonów w pejzażu akustycznym stołecznej metropolii, malarstwo i rzeźba, witraże, zapach świec i kadzidła), "starożytnictwo" (antiquarianism), czyli nawiązywanie do minionych stylów i estetyk, najchętniej średniowiecznych (gotycyzm, neogotyk, dawny folklor), plebejskość, ludyczność i poczucie humoru. Istotę kultury angielskiej widzi Ackroyd - zdaniem Niedokosa - w płynnym łączeniu przeciwieństw: racjonalizmu i wizjonerstwa, pragmatyzmu i mistyki, bezreligijności i wiary. To zupełnie inny obraz Anglii od jej współczesnego stereotypowego wizerunku, w którym dominującymi punktami są monarchia, imperializm, angielskie ziemiaństwo, understatement i Oxbridge.

Komuś, kto - jak pisząca te słowa - nie jest obdarzony „katolicką wrażliwością", a lubi i ceni twórczość Petera Ackroyda, nie jest łatwo zweryfikować rozpoznania Tomasza Niedokosa, ale z pewnością skłaniają one do refleksji i ponownej lektury książek autora Golema z Limehouse. W ich świetle również kwestia Ackroydowskiej biografilii zyskuje dodatkowy wymiar, można bowiem w niej się dopatrzyć kolejnego reliktu katolickości z jej kultem świętych i hagiografią. Biografie Ackroyda - przynajmniej te „wielkie”, sprzed komercyjnej fazy jego pisarstwa - noszą przecież liczne znamiona narracji martyrologicznych, kładąc nacisk na takie wątki, jak udręki dzieciństwa i młodości (Dickens), ubóstwo i wizjonerstwo (Blake) czy męczeńska śmierć w imię zasad wiary (The Life of Thomas More). W Polsce książki Ackroyda (wydawane przez Zysk i S-ka) trafiają na dobry grunt czytelniczy, ale wydaje się, że z ich lektury możemy wynieść znacznie więcej intelektualnego pożytku niż to się na pierwszy rzut oka wielu czytelnikom wydaje. 


\section{Abstract}

\section{Ewa Kraskowska}

ADAM MICKIEWICZ UNIVERSITY (POZNAŃ)

Biographilia: The Case of Peter Ackroyd

In this article on the British writer and critic Peter Ackroyd Kraskowska focuses on the biographical narratives that pervade his work: narratives of the lives of London-based writers and artist (e.g. Dickens, Blake, T.S. Eliot), novels built on biographical details, and "biographies"(Ackroyd's term) of cities such as London or Venice. Borrowing Cory Kaplan's notion of "biographilia," which refers to the current revival of biographical narratives that hark back to nineteenth-century models of the genre, Kraskowska also contextualises Ackroyd's work with the British tradition of life writing, postmodern aesthetics, the neoVictorian novel fiction as well as Tomasz Niedokos's concept of English Catholic literature.

\section{Keywords}

Peter Ackroyd, Virginia Woolf, Lytton Strachey, London, biographilia, neo-Victorianism, postmodernism, Catholicism 